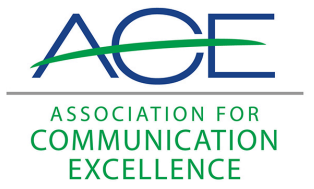

Journal of Applied Communications

\title{
Further Evidence on Using a Deadline to Stimulate Responses to a Mail Survey; Readership and Coverage of Science and Technology in Newspapers; The Uses and Gratifications Approach to Mass Communications Research
}

Larry Meiner

Lloyd R. Bostian

Follow this and additional works at: https://newprairiepress.org/jac

(c) (1) (2) (2)

This work is licensed under a Creative Commons Attribution-Noncommercial-Share Alike 4.0 License.

\section{Recommended Citation}

Meiner, Larry and Bostian, Lloyd R. (1979) "Further Evidence on Using a Deadline to Stimulate Responses to a Mail Survey; Readership and Coverage of Science and Technology in Newspapers; The Uses and Gratifications Approach to Mass Communications Research," Journal of Applied Communications: Vol. 62: Iss. 3. https://doi.org/10.4148/1051-0834.1876

This Review is brought to you for free and open access by New Prairie Press. It has been accepted for inclusion in Journal of Applied Communications by an authorized administrator of New Prairie Press. For more information, please contact cads@k-state.edu. 


\title{
Further Evidence on Using a Deadline to Stimulate Responses to a Mail Survey; Readership and Coverage of Science and Technology in Newspapers; The Uses and Gratifications Approach to Mass Communications Research
}

\author{
Abstract \\ Reviews of Further Evidence on Using a Deadline to Stimulate Responses to a Mail Survey by Robert \\ Roberts, Owen McCrory and Ronald Forthofer; "Readership and Coverage of Science and Technology in \\ Newspapers," by Clyde Z. Nunn; "The Uses and Gratifications Approach to Mass Communications \\ research," edited by David L. Swanson.
}




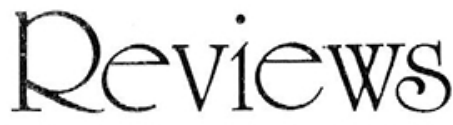

Reviews are prepared by Larry Meiller, Lloyd R. Bostian and others in the Department of Agricultural Journalism, University of Wisconsin-Madison.

Further Evidence on Using a Deadline to Stimulate Responses to a Mail Survey, Robert Roberts, Owen McCrory and Ronald Forthofer, Vol. 42, No. 3, fall 1978, pp. 407-410.

Respondents were 1109 dentists. Their deadline was specified as: "If we have not heard from you in three weeks we will contact you again." Two mail follow-ups were sent four weeks apart, with the first four weeks after the initial mailing.

Responses after the mailing were nearly 35 percent for the deadline version and nearly 28 percent where a deadline was not given. The final response rates were more than 70 percent versus nearly 68 percent. Apparentiy the main effect of specifying a return deadline is to speed up returns. Beyond the deadline response rates tend to converge. However, even though final response rates may not differ greatly, getting returns early does reduce costs.

"Readership and Coverage of Science and Technology in Newspapers.' Clyde Z. Nunn. Journalism Quarterly, Vol. 46, No. 1, spring 1979.

Claims persist in our country that the public has lost confidence in science and technology. This crisis of confidence is said to mask the fact there has been a loss of interest in science if not downright anti-scientism. However, this research presents evidence that editors are clearly underestimating public interest in science news.

The author conducted a secondary analysis of two 
Newspaper Advertising Bureau surveys conducted in 1971 and 1977. Both surveys were designed to obtain information on editorial content of daily newspapers and on readership patterns among adults over 18 . In both, personal interviews were conducted and respondents were asked to rate their interest in articles found throughout the papers.

Nunn found that science articles were considered to be among the most interesting of all editorial items in the 1977 sample. Nearly one of every four editorial items were rated "very interesting" while nearly one of every three articles on science and inventions were rated "very interesting." Thirty-four percent of the science and invention items were considered "somewhat interesting" and one fourth were rated as "not interesting." The remaining 9 percent gave no answer.

Interest in science and technology appears to be increasing as well. In the 1971 survey, the science and invention category was not among the 17 content categories most often read. By 1977, articles in this category ranked eleventh. Also, the science-related categories of energy, public health and environment ranked first, third and sixth, respectively among the content categories in the proportion of stories rated "very interesting.'

Many people feel that the young of this country have turned away from scientific rationality and have developed a counter culture that places greater credence in other ways of knowing. His findings do not bear out that view. He found that young adults are more likely than older adults to rate science articles in newspapers as "very interesting." This finding is noteworthy since younger people generally give lower ratings of "very interesting" than older people.

The author noted that despite the interest in science-related stories, the studies show the percentage of newspaper editorial content devoted to them has actually declined (from one percent in 1971 to .7 percent in 1977). By contrast, puzzles and horoscopes claimed 2.4 percent of editorial content space in 1971 and had increased to 2.9 percent by 1977 . Yet respondents rated these items among the least desirable. 
Nunn concluded that to give science increased prominence would help maintain frequent readers' interest and could activate infrequent readers to become frequent ones. ACE members might want to share these findings with local editors.

"The Uses and Gratifications Approach to Mass Communications research," Edited by David L. Swanson, Communication Research, Vol. 6, No. 1, January, 1979.

The growing popularity of the uses and gratifications approach to mass communications research is no doubt obvious to anyone who reads the communications journal. It is an intriguing approach to research in our field, because of its emphasis on theory.

A good bit of the early communications research treated theory as secondary in importance to attempting to learn such things as what the media do to people. This research does not deal with effects of media on people. Instead it examines what people do with the media. As Swanson notes, the audience is not viewed as passive receivers of the powerful media messages.

The issues related to this research are assessed, debated and exemplified in the papers which comprise this special edition of Communication Research. The papers probe issues and problems currently regarded as important by both critics and practitioners of the uses and gratification approach.

Some issues center on whether the approach is a general theory of communication. Jay Blumler, one of the authors, argues the approach is not to be viewed as a "grand theory," but rather as a group of basic commitments comprising a research framework. Swanson counters that such a view usually leads to conceptual ambiguities and inconsistencies in the approach.

The papers also focus more narrowly on ways to measure gratifications. They present findings on the degree to which we can discuss the nature of gratificationa by locating their origins in people's social circumstances.

The papers presented in this journal offer a fairly 
complete assessment of the current state and future of the uses and gratifications approach. It is definitely recommended reading for anyone with an interest in this research area. Aside from the contributions by Blumler and Swanson, articles by Lee Becker, Elihu Katz and Hanna Adoni are included. 
Meiner and Bostian: Further Evidence on Using a Deadline to Stimulate Responses to a 